\title{
Detrital zircon U-Pb geochronology of a metasomatic calc-silicate in the Tsäkkok Lens, Scandinavian Caledonides
}

\author{
Christopher J. Barnes ${ }^{1}$, Jarosław Majka², Michał Bukała ${ }^{3}$, Erika Nääs \\ Sabine Rousku ${ }^{5}$
}

${ }^{1}$ Polish Academy of Sciences, Institute of Geological Sciences, Krakow, Poland; AGH University of Science and Technology, Faculty of Geology, Geophysics and Environmental Protection, Krakow, Poland;

e-mail: cjbarnes063@gmail.com; ORCID ID:0000-0003-0597-7999

${ }^{2}$ AGH University of Science and Technology, Faculty of Geology, Geophysics and Environmental Protection, Krakow, Poland; Uppsala University, Department of Earth Sciences, Uppsala, Sweden; e-mail: jaroslaw.majka@geo.uu.se; ORCIDID:0000-0002-6792-6866

${ }^{3}$ AGH University of Science and Technology, Faculty of Geology, Geophysics and Environmental Protection, Krakow, Poland; e-mail:michal.bukala91@gmail.com; ORCID ID: 0000-0001-7045-3150

${ }^{4}$ Uppsala University, Department of Earth Sciences, Uppsala, Sweden; e-mail:erikanaas@hotmail.com; ORCID ID:0000-0003-1421-3448

${ }^{5}$ Uppsala University, Department of Earth Sciences, Uppsala, Sweden;

e-mail: sabine.rousku@hotmail.com; ORCID ID: 0000-0002-0891-2130

(C) 2021 Authors. This is an open access publication, which can be used, distributed and reproduced in any medium according to the Creative Commons CC-BY 4.0 License requiring that the original work has been properly cited.

Received: 14 January 2021; accepted: 25 February 2021; first published online: 23 April 2021

\begin{abstract}
The Tsäkkok Lens of the Seve Nappe Complex in the Scandinavian Caledonides comprises eclogite bodies hosted within metasedimentary rocks. These rocks are thought to be derived from the outermost margin of Baltica along the periphery of the Iapetus Ocean, but detrital records from the sedimentary rocks are lacking. Many metasedimentary outcrops within the lens expose both well-foliated metapelitic rocks and massive calc-silicates. The contacts between these two lithologies are irregular and are observed to trend at all angles to the high-pressure foliation in the metapelites. Where folding is present in the metapelites, the calc-silicate rocks are also locally folded. These relationships suggest metasomatism of the metapelites during the Caledonian orogenesis. Zircon U-Pb geochronology was conducted on sixty-one zircon grains from a calc-silicate sample to investigate if they recorded the metasomatic event and to assess the detrital zircon populations. Zircon grains predominantly show oscillatory zoning, sometimes with thin, homogeneous rims that have embayed contacts with the oscillatory-zoned cores. The zircon cores yielded prominent early Stenian, Calymmian, and Statherian populations with a subordinate number of Tonian grains. The zircon rims exhibit dissolution-reprecipitation of the cores or new growth and provide ages that span similar time frames, indicating overprinting of successive tectonic events. Altogether, the zircon record of the calc-silicate suggests that the Tsäkkok Lens may be correlated to Neoproterozoic basins that are preserved in allochthonous positions within the northern extents of the Caledonian Orogen.
\end{abstract}

Keywords: Scandinavian Caledonides, Seve Nappe Complex, Tsäkkok Lens, metasomatism, detrital zircon U-Pb geochronology 


\section{INTRODUCTION}

The architecture of the Scandinavian Caledonides provides an excellent record of Wilson-cycle tectonics from ocean basin formation, closure, and subsequent continental collision (e.g., Gee et al. 2008). During Caledonian orogenesis, the continental crust of the Baltican margin was subducted to mantle depths beneath an Iapetus oceanic arc complex (e.g., Gee et al. 2020, Stephens et al. 2020). Exhumed remnants of the subducted Baltican crust are represented by the Seve Nappe Complex (SNC), preserving multiple localities of ultra-high pressure (UHP) to high pressure (HP) metamorphic rocks (e.g., Gee et al. 2013, 2020). In southern Norrbotten, the Tsäkkok Lens (the focus of this study; Fig. 1) and the tectonically underlying Vaimok Lens (e.g., Zachrisson \& Stephens 1984, Andréasson 2020) both comprise siliciclastic and calcareous metasedimentary rocks that host eclogites (Kullerud et al. 1990, Andréasson \& Albrecht 1995, Andréasson 2020). In the
Tsäkkok Lens, some of the eclogite protoliths are recognized as pillow basalts (Kullerud et al. 1990), whereas the eclogite protoliths for the Vaimok Lens are interpreted to be mafic dykes (Andréasson \& Albrecht 1995), and all are interpreted to be related to rifting and Iapetus Ocean formation (e.g., Andréasson \& Albrecht 1995, Root \& Corfu 2012, Gee et al. 2013, Gee et al. 2020). The metasedimentary lithologies are generally similar, consisting of quartzites, metapsammites, metapelites, calc-silicates, and marbles (e.g., Andréasson 2020) but the pelitic and calcareous lithologies are much more prevalent in the Tsäkkok Lens compared to the Vaimok Lens (Kullerud et al. 1990, Albrecht 2000).

The timing of eclogite-facies metamorphism is similar for both lenses at c. $482 \mathrm{Ma}$ (Root \& Corfu 2012, Fassmer et al. 2021) but the metamorphic conditions for the Tsäkkok Lens $(\sim 2.5 \mathrm{GPa}$ and $\sim 620^{\circ} \mathrm{C}$; Bukała et al. 2020a, Fassmer et al. 2021) are lower than the conditions for the Vaimok Lens ( 3.0 GPa and $\sim 720^{\circ} \mathrm{C}$; Bukała et al. 2018).

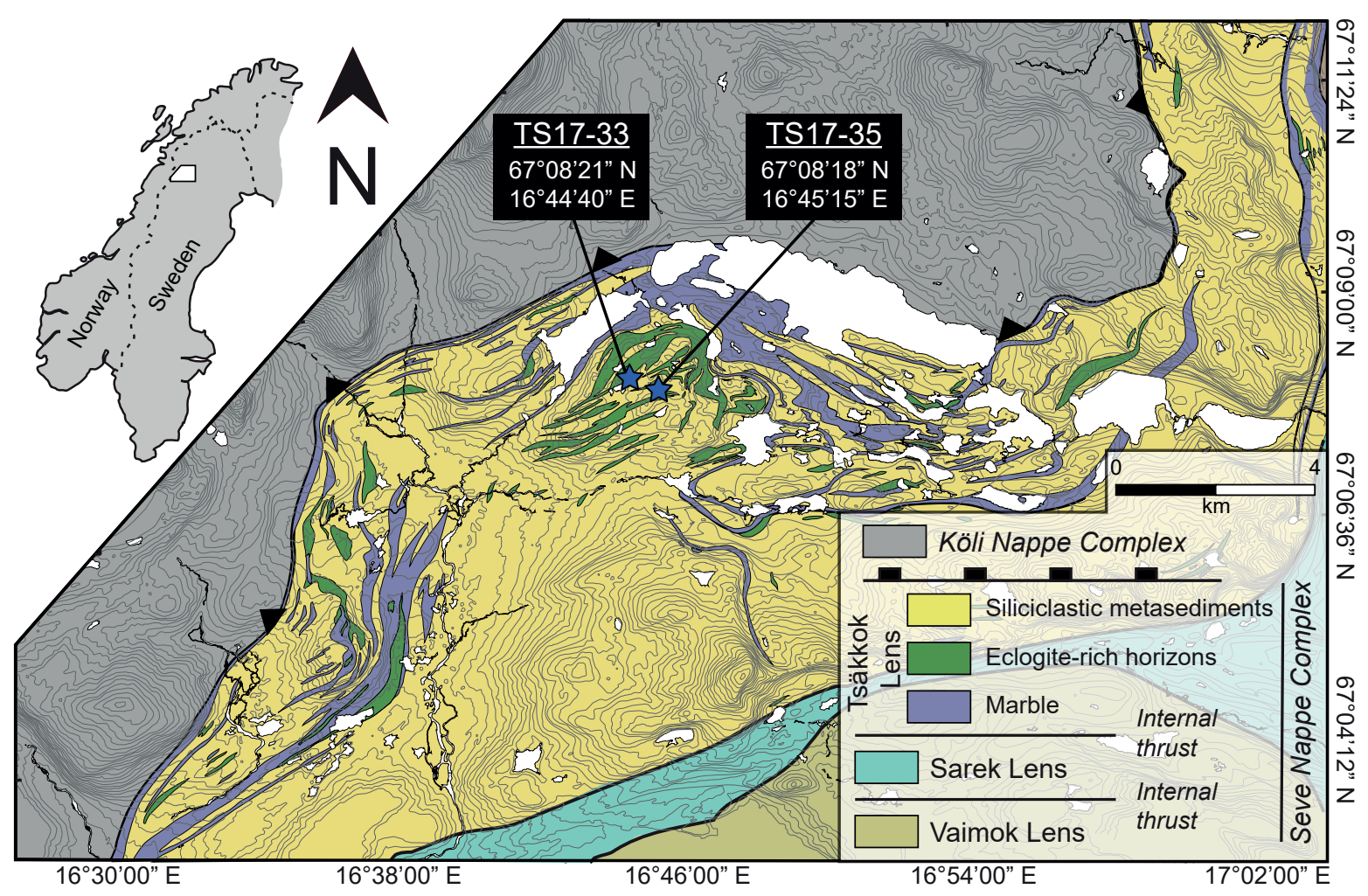

Fig. 1. Geological map of the Tsäkkok Lens (modified after Kullerud et al. 1990, Barnes et al. 2020b). The locations and GPS co-ordinates of the two outcrops discussed in the main text are provided on the map. The map location in northern Sweden is denoted by the white polygon on the greyscale map of Norway and Sweden 
Influx of Ca-rich fluids in the Vaimok Lens was recorded during exhumation of the lens by both eclogites (Bukała et al. 2018) and metasedimentary rocks (Barnes et al. 2019). Dehydration and fluid migration within the Tsäkkok Lens eclogites at high pressure conditions was recently documented by Bukała et al. (2020a), but a similar instance of Ca-rich fluid influx in the lens has not been documented during exhumation. Nevertheless, the timing and conditions of eclogite-facies metamorphism suggest common history of subduction and exhumation during Caledonian orogenesis for the two lenses (Andréasson 2020). However, a potential correlation of the Tsäkkok Lens with the Vestgötabreen Complex on Svalbard (Barnes et al. 2020a) may suggest the Tsäkkok Lens originated from a more northerly position before Caledonian orogenesis and is not closely related to the Vaimok Lens in Neoproterozoic time. Detrital zircon records have been reported for the Vaimok Lens (Gee et al. 2015, Barnes et al. 2019) but no such studies have been conducted in the Tsäkkok Lens to compare the provenance of the metasedimentary rocks.

In this study, we apply $\mathrm{U}-\mathrm{Pb}$ geochronology to detrital zircon grains from a calc-silicate in the Tsäkkok Lens that provides a clear and well-exposed record of metasomatism. In the Vaimok Lens, a previous study (Barnes et al. 2019) was successful at dating fluid influx and related metamorphism in the metasedimentary rocks by investigating the zircon rims in the metasediments. The concept was similar for the Tsäkkok Lens to evaluate if metasomatism occurred at a similar time as in the Vaimok Lens, thus providing potential link between the Vaimok and Tsäkkok lenses during the subduction-exhumation process. Furthermore, the sedimentary provenance of the calc-silicate was investigated to compare with provenance data of the Vaimok Lens (e.g., Gee et al. 2015, Barnes et al. 2019) and explore possible correlations between the Tsäkkok Lens and Neoproterozoic basins that are preserved in allochthonous positions in more southerly and northerly locations in the Caledonides.

\section{FIELD OBSERVATIONS}

Fieldwork was conducted in the Tsäkkok Lens to identify the structures and relationships of the various lithologies. Two key outcrops (named TS17-33 and TS17-35; Fig. 1) were chosen to demonstrate field relationships between mica schists and calc-silicates (Fig. 2). The mica schists are generally well-foliated whereas the calc-silicate rocks are massive. At both outcrops, the boundary between the mica schist and the calc-silicate is highly irregular and both parallels and transects the foliation of the mica schists (Fig. 2A-D). At outcrop 'TS17-33', the foliation 'S1' was interpreted to have developed during prograde to peak metamorphism and is folded by $\mathrm{cm}$-scale $\mathrm{F} 2$ folds that formed during exhumation of the lens (Barnes et al. 2020b). Locally, the foliation is cut by the contact with the calc-silicate (Fig. 2B). However, extensions of the calc-silicate into the mica schist parallel to $S 1$ are observed to be folded along with the F2 folds in the mica schist (Fig. 2D). At outcrop 'TS17-35', the calc-silicate is clearly folded in a pattern that resembles F2 (Fig. 2E), based on the description by Barnes et al. (2020b).

\section{PETROGRAPHIC OBSERVATIONS}

Several samples of the mica schists and calc-silicate rocks were obtained. Standard $30 \mu \mathrm{m}$ thin sections were cut from the samples for transmitted light microscopy and back-scattered electron imaging (Fig. 3). Back-scattered electron (BSE) images was done with the Jeol JXA8230 Superprobe at AGH University of Science and Technology, Kraków, Poland. The mica schists are dominated by white mica, with minor replacement of biotite or chlorite, and also contain garnet (occasionally pseudomorphed by chlorite), plagioclase, and quartz (Fig 3A). Accessory minerals can include titanite, monazite, apatite, allanite, clinozoisite, and zircon. Notably, monazite is found as relics within coronas of apatite, allanite and clinozoisite. The mica schists are well-foliated, with a foliation defined by the alignment of white mica and quartz bands, and are often folded on the $\mathrm{cm}$-scale (Fig 3A). The main minerals of the calc-silicate are epidote, plagioclase, calcite, quartz, muscovite, biotite, or chlorite (Fig. 3B-D). Accessory phases include titanite and zircon. No foliation development or folding of the calc-silicate rocks are observed in thin section. 


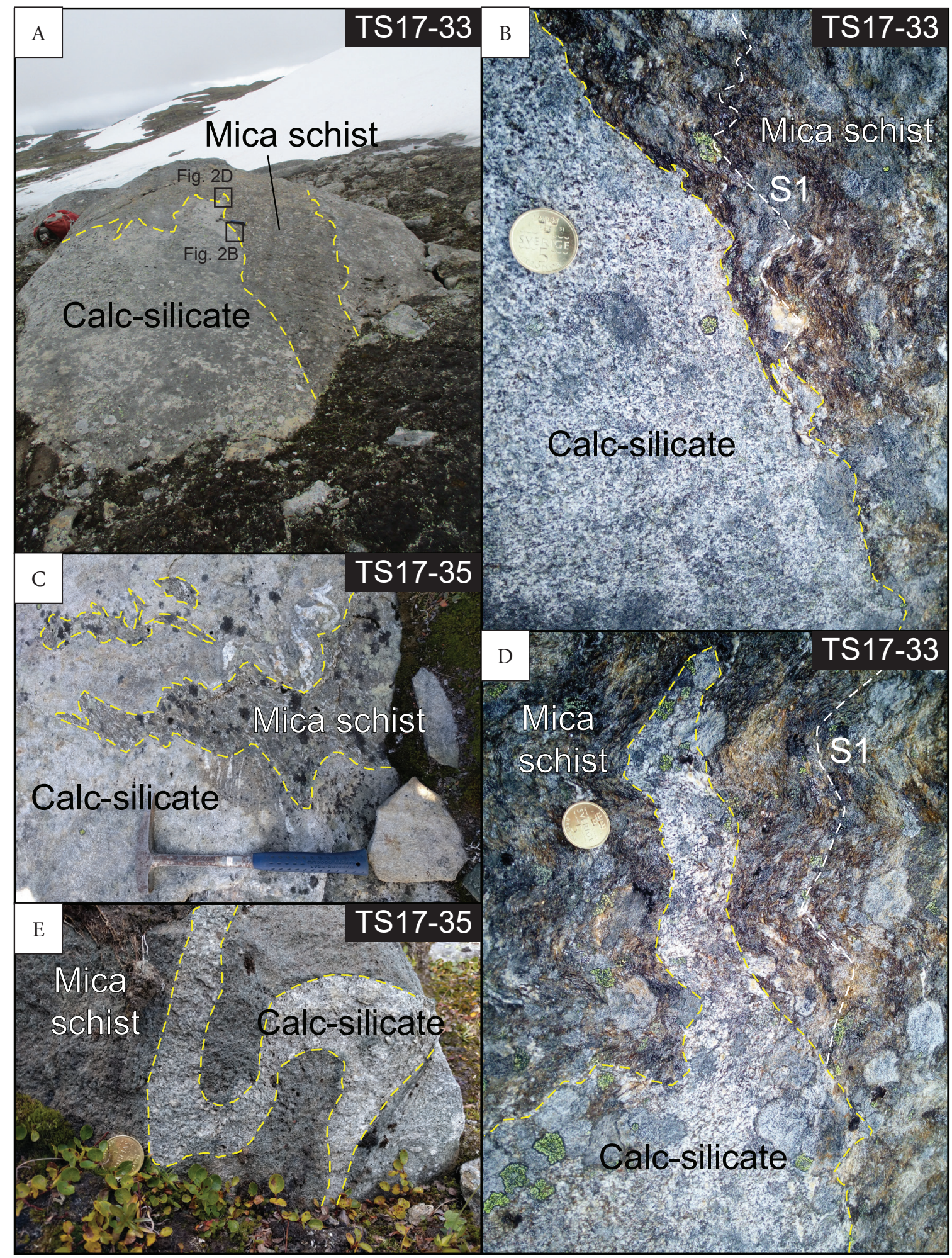

Fig. 2. Field photos from the two outcrops showing the relationships between mica schists and calc-silicates. The contact between the two lithologies is demarcated by the yellow dashed line, whereas the 'S1' foliation (where applicable) is traced by the white dashed line. Scales are provided by hammers or coins: A) outcrop TS17-33, where the massive calc-silicate has a highly irregular contact with the well-foliated mica schist; B) close-up of where the contact cross-cuts the 'S1' foliation of the mica schists; C) highly irregular contact between a calc-silicate and a mica schist. Vestiges of the foliated mica schist can be observed within the calc-silicate; D) folding of a calc-silicate layer within a mica schist; the folding resembles ' $F 2$ ' folds described by Barnes et al. (2020b); E) a narrow extension of the calc-silicate into the mica-schist parallel to S1. Note that the extension of the calc-silicate is folded along with the mica schist 


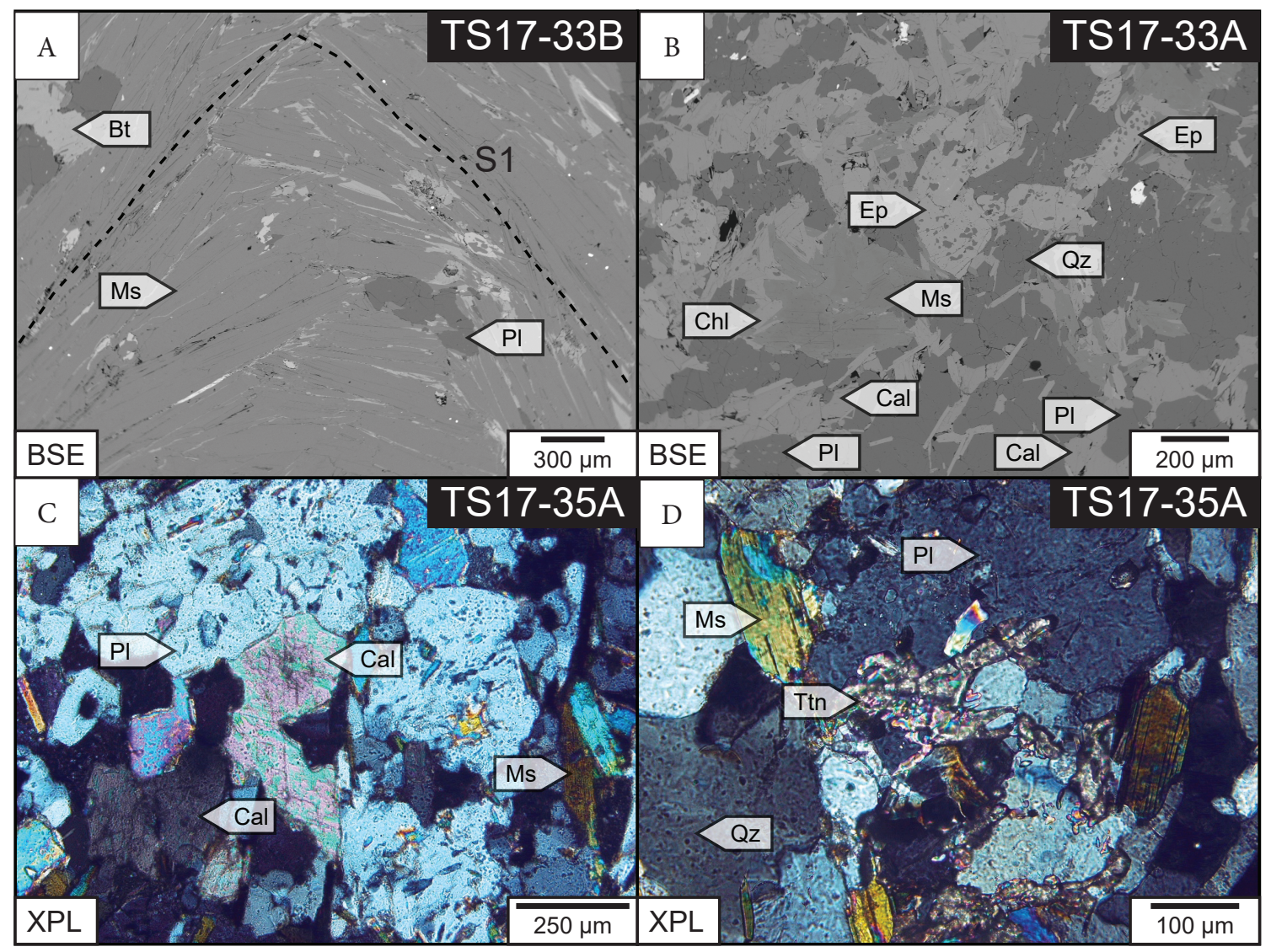

Fig. 3. Photomicrographs of the metasedimentary rocks of the Tsäkkok Lens: A) back-scattered electron image of a mica schist from outcrop TS17-33 that is dominated by white mica that defines S1 and folded by F2; B) back-scattered electron image of a sample from the massive calc-silicate from outcrop TS17-33; C) and D) cross-polarized transmitted light images of a sample from the massive calc-silicate from outcrop TS17-35

\section{ZIRCON U-PB GEOCHRONOLOGY}

A calc-silicate sample from outcrop 'TS17-35' was crushed using standard crushing techniques. The disaggregated sample was sieved to extract the 60-250 $\mu \mathrm{m}$ size fraction. This fraction was further processed using heavy liquid density separation to obtain a heavy mineral concentrate. Using a binocular microscope, zircon grains were identified and hand-picked. These zircon grains were mounted into an epoxy that was subsequently polished to expose the zircon cores for $\mathrm{U}-\mathrm{Pb}$ geochronology. To identify locations for analysis, the zircon interiors were imaged using BSE and cathodoluminescence (CL) imaging with a JEOL 6610LV scanning electron microprobe at the University of Ottawa. An accelerating voltage of $15 \mathrm{KeV}$ was used for the imaging.
Zircon $\mathrm{U}-\mathrm{Pb}$ geochronology was conducted using a Photon Machines Analyte Excite $193 \mathrm{~nm}$ excimer laser attached to an Agilent 7700x ICP-MS (LA-ICP-MS) at the University of Ottawa (Ottawa, Canada). A $26 \mu \mathrm{m}$ beam diameter was used at a repetition rate of $11 \mathrm{~Hz}$ and fluence of $5.31 \mathrm{~J} / \mathrm{cm}^{2}$. A helium carrier and argon makeup gas flow were 0.985 and $0.75 \mathrm{l} / \mathrm{min}$ respectively. ${ }^{140} \mathrm{Ce}$ was used to monitor for sharp peaks indicative of ablation of an inclusion. ${ }^{204} \mathrm{~Pb}$ was monitored; counts during ablation were not significantly different from background levels and thus no common lead correction was applied. Zircon '91500' (Wiedenbeck et al. 1995) was used for internal calibration while Plešovice zircon (Sláma et al. 2008) was used as secondary reference material for accuracy assessment. The reference materials were measured at the beginning 
and end of the ablation session and for every six unknown analyses. Data reduction was done using GLITTER v4.4 (www.glitter-gemoc.com). Uncertainties on individual analyses are reported at the $1 \sigma$ level. Further zircon analysis of the same sample was conducted using standard $30 \mu \mathrm{m}$ thin sections. Zircon in the sections were located and BSE images were obtained using a JEOL JXA8530F EMP at Uppsala University (Uppsala, Sweden). Zircon $\mathrm{U}-\mathrm{Pb}$ geochronology of the thin sections was conducted at the Vegacenter in the Swedish Museum of Natural History (Stockholm, Sweden). The detailed methodology can be found in Bukała et al. (2020b). The individual uncertainties are reported at the $2 \sigma$ level.

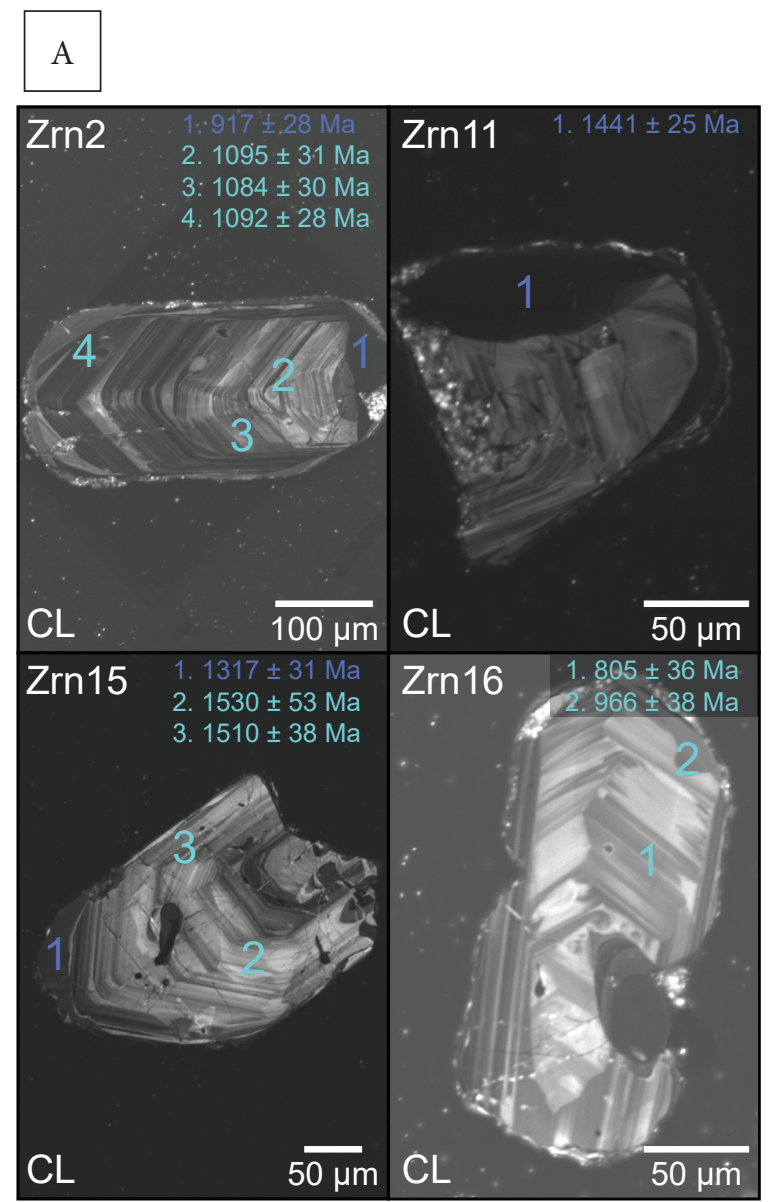

The zircon grains are generally sub-rounded to rounded and elongate in shape. The BSE and CL images of the zircon cores revealed that they are predominantly characterized by oscillatory zoning with one grain showing sector zoning (Fig. 4A). The zonation of the cores often ends abruptly at the grain edge or at boundaries with thin, unzoned zircon domains. The boundaries are sharp and sometimes embayed towards the zircon core. Both the zircon cores and rims were targeted for $\mathrm{U}-\mathrm{Pb}$ geochronology. Sixty-one zircon grains were dated with a collective one hundred and nine analyses obtained from the zircon cores, and only five analyses acquired from the rims as they were frequently thinner than the beam diameter that was used.

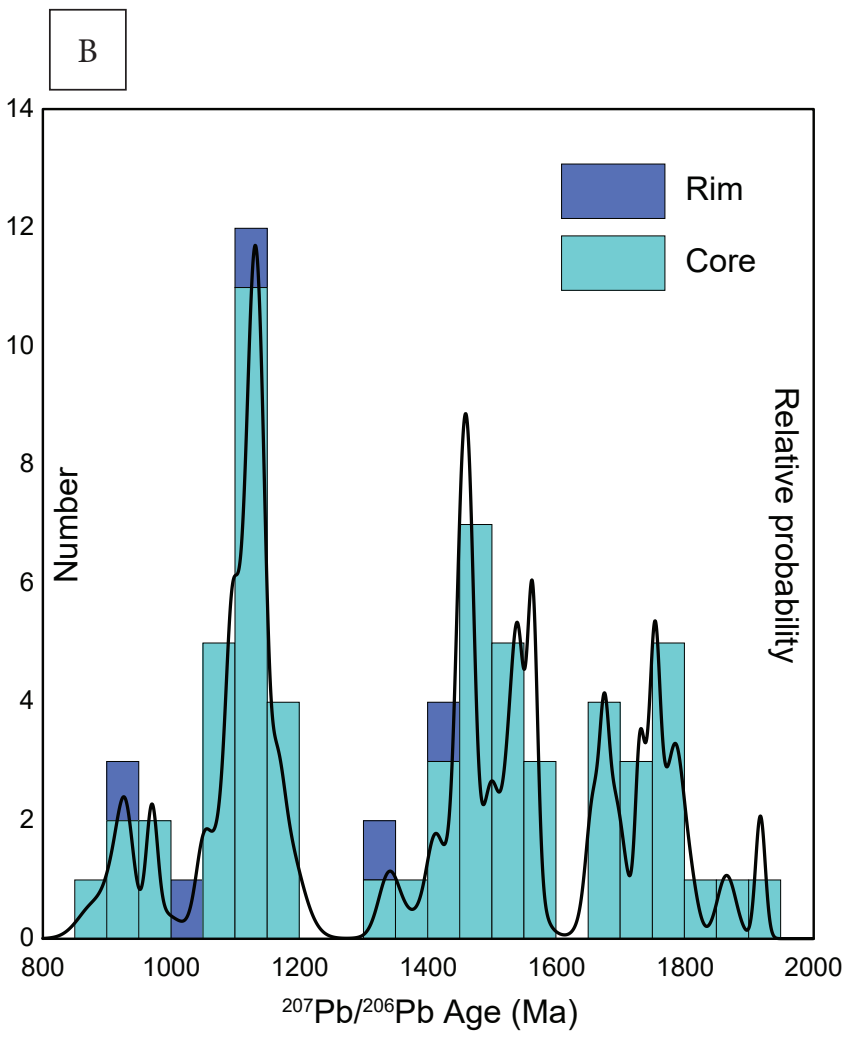

Fig. 4. Cathodoluminescence images of representative zircon grains with cores and rims. The name of each zircon is written in the top-left corner of each image. The analytical locations are labelled on each zircon grain with numbers that correspond to the ${ }^{207} \mathrm{~Pb} /{ }^{206} \mathrm{~Pb}$ ages written in the top-right corner of each image. The rim analyses are written in dark blue, whereas the core analyses are written in light blue (A). Histogram of comprising the weighted average ${ }^{207} \mathrm{~Pb} /{ }^{206} \mathrm{~Pb}$ age for the cores (light blue) and individual ${ }^{207} \mathrm{~Pb} /{ }^{206} \mathrm{~Pb}$ age for the rims (dark blue). The black line represents the relative probability of the histogram for the core $\operatorname{ages}(B)$ 
Weighted averages of the ${ }^{207} \mathrm{~Pb} /{ }^{206} \mathrm{~Pb}$ age were calculated for multiple points on the same zircon cores (Fig. 4B; Tabs. S1 and S2 - attached as supplementary files in online version). The weighted average ${ }^{207} \mathrm{~Pb} /{ }^{206} \mathrm{~Pb}$ ages can be grouped as $883 \pm 52 \mathrm{Ma}$ to $979 \pm 68 \mathrm{Ma}(n: 5), 1050 \pm 24 \mathrm{Ma}$ to $1187 \pm 46 \mathrm{Ma}$ ( $n: 20), 1339 \pm 32 \mathrm{Ma}$ to $1565 \pm 14 \mathrm{Ma}(n: 20)$, and $1657 \pm 20 \mathrm{Ma}$ to $1804 \pm 26 \mathrm{Ma}(n: 13)$ with two more individual ages of $1864 \pm 29 \mathrm{Ma}$ and $1917 \pm 15 \mathrm{Ma}$. Single ages of the zircon rims are $917 \pm 28 \mathrm{Ma}$, $1046 \pm 31 \mathrm{Ma}, 1126 \pm 33 \mathrm{Ma}, 1317 \pm 31 \mathrm{Ma}$, and 1441 $\pm 25 \mathrm{Ma}$. The rim dates are all younger than the ages for their respective cores (Fig. 4B, Tab. S1). Analyses of the zircon cores and rims are typically concordant except for the oldest zircon rim, which exhibits $\sim 16 \%$ normal discordance.

\section{DISCUSSION}

The outcrop relationships, both lithological and structural, indicate that the calc-silicate rocks were formed due to metasomatism. The irregular boundary of the calc-silicate with the mica schist represents the metasomatic front (Fig. 2). Provided that the metasomatic front seemingly transects the prograde-to-peak S1 and that the calc-silicate is not itself foliated (Figs. 2 and 3), the metasomatic events likely occurred during metamorphism of the Tsäkkok Lens during subduction or perhaps during exhumation as the calc-silicates are folded by $\mathrm{F} 2$ folds. It is also possible that metasomatism proceeded in diagenetic conditions prior to subduction, although that would be difficult to explain considering the foliated vestiges of the mica schist that can be observed within the massive calc-silicates (Fig. 2C).

Fluid activity related to dehydration of eclogite bodies within the Tsäkkok Lens at high pressure conditions was recently presented by Bukała et al. (2020a). Furthermore, documentation of the influx of Ca-rich fluids is recorded in the Vaimok Lens during exhumation by both eclogites (Bukała et al. 2018) and the metasedimentary rocks (Barnes et al. 2019). Influx in the latter is evinced by retrogression of monazite to form coronas of apatite, allanite and clinozoisite, similar to observations for the Tsäkkok Lens mica schists, and also recorded by thin, irregular zircon rims that formed by dissolution-reprecipitation of detrital cores. The fluids responsible for metasomatism are Ca-rich, similar to the fluid composition interpreted for metasomatism of the Tsäkkok Lens. The zircon grains in the calc-silicate apparently did not react with the Ca-rich fluids as they did in the Vaimok Lens. Instead, the rims of the zircon from the Tsäkkok Lens mica schists yielded dates from early Neoproterozoic to middle Mesoproterozoic time and do not show Caledonian signatures (Fig. 4A). Provided the irregular boundaries of these zircon rims with the cores, they likely represent dissolution-reprecipitation or growth due to subsequent magmatic or metamorphic events, representing recycling of the zircon grains through multiple tectonic episodes. It is possible that the temperature conditions of the metasomatic event(s) during Caledonian orogenesis influenced how the fluids reacted with zircon, as exhumation of the Vaimok Lens proceeded through hotter temperatures (up to $\sim 750^{\circ} \mathrm{C}$; Bukała et al. 2018) than compared to the maximum temperature of the Tsäkkok Lens $\left(\sim 620^{\circ} \mathrm{C}\right.$; Bukała et al. 2020a).

The zircon grains that were dated are characteristic of detrital zircon that were deposited as part of the protoliths of the mica schist and not related to metasomatism and formation of the calc-silicate rocks. Although the number of detrital grains that were dated ( $n: 60)$ is not statistically optimal (Vermeesch 2004, Coutts et al. 2019), the dataset provides a good first-order assessment of the significant populations. Overall, the detrital record is dominated by early Stenian, Calymmian, and Statherian material, with a subordinate Tonian record (Fig. 4B; Bingen et al. 2008, Bingen \& Solli 2009). Sources for Tonian, Calymmian and Statherian zircon are widespread throughout the North Atlantic Region (Bingen et al. 2008, Bingen \& Solli 2009), whereas sources for early Stenian provenance are seldom. In general, the early Stenian population is not typical for detrital zircon signatures throughout the SNC and underlying nappes, which are rather dominated by late Stenian populations (e.g., Be'eri-Shlevin et al. 2011, Kirkland et al. 2011, Ladenberger et al. 2014, Gee et al. 2014, 2015, Barnes et al. 2019). In southern Norrbotten, late Stenian populations dominate the Sarek Lens and the Grapesvare Nappe of the Vaimok Lens (Barnes et al. 2019, Kjøll 2020). The Maddåive Nappe, thought to be within the Vaimok Lens (Albrecht 2000), contains a dominant early 
Stenian population while lacking late Stenian zircon (Gee et al. 2015). Interestingly, the Maddåive Nappe has also been mapped as a correlative to the Tsäkkok Lens (Thelander 2009). If indeed it is the case, then the Tsäkkok Lens may not share a common history with the Sarek or Vaimok lenses in the Neoproterozoic.

It is difficult to ascribe the affinity of the Tsäkkok Lens to Baltica or Laurentia using the detrital zircon record (Slagstad \& Kirkland 2017), however, the presence of the early Stenian population allows for exploration the lens' origin with respect to vestiges of Neoproterozoic basins preserved in the Caledonides in more southerly or northerly locations. Early Stenian sources are rare within both Grenvillian and Sveconorwegian orogens in general. Potential southern sources are from the Adirondack Mountains and the Frontenac terrane in the Grenville Orogen (e.g., McLelland et al. 2004, Peck et al. 2013), and the Telemarkia and Bamble-Kongsberg terranes in the Sveconorwegian Orogen (Bingen \& Solli 2009). However, the early Stenian magmatic suites in the Grenville Orogen are hosted within a regional setting that was dominated by Ectasian tectonic activity (e.g., Hanmar et al. 2000). The apparent lack of Ectasian record in the Tsäkkok Lens (Fig. 4) does not support derivation of the early Stenian grains from the Grenville Orogen. The Telemarkia terrane, and the nearby Idefjorden terrane and the Eastern Segment of the orogen, also contain Ectasian magmatic suites although they are volumetrically subordinate (Bingen \& Solli 2009, Bergström et al. 2020, Stephens \& Wahlgren 2020). Furthermore, the Bamble-Kongsberg terrane lacks Ectasian rocks and has been shown to tectonically overlie the Telemarkia terrane to the west (Andersson et al. 1996, Ebbing et al. 2005). In Neoproterozoic time, it could have been a more prominent source terrane supplying early Stenian material without the input of Ectasian detritus. Indeed, the Särv and Sætra nappes in the southern Caledonides both contain early Stenian detrital zircon records with subordinate Ectasian zircon populations, similar to the Tsäkkok Lens, but they are also dominated by late Stenian material (Be'eri-Schlevin et al. 2011, Gee et al. 2014). Therefore, it is plausible that the Tsäkkok Lens was supplied by the Bamble-Kongsberg terrane, but if related to deposition of the Särv and Sætra nappes, it would require an explanation as to why late Stenian source terrains do not appear to have contributed to the deposition of the lens yet provided a significant source for the nappes.

Early Stenian source terrains are not identified in northern Scandinavia, Greenland nor other regions of the high Arctic (e.g., on Svalbard), yet there are instances of early Stenian detrital zircon records in northern basins. One hypothesis is that the source terrains of the late Mesoproterozoic detritus (including early Stenian zircons) were lost due to subduction of Sveconorwegian crust during Caledonian orogenesis (Gee et al. 2017). Examples of such northern basins' sedimentary successions are the Nyborg Formation within the Gaissa Nappe in the northern Scandinavian Caledonides (Gee et al. 2017) and the Slyngfjellet Formation of the Sofiebogen Group in the Svalbardian Caledonides (Wala et al. 2021). Both formations contain dominant early Stenian detrital zircon records with subordinate late Stenian contributions. These formations are also thought to be deposited during late Cryogenian to early Ediacaran time (e.g., Jensen et al. 2018, Ziemniak et al. 2019, Wala et al. 2021). Considering the presence of pillow basalts that are likely related to rifting and incipient opening of the Iapetus Ocean (Kullerud et al. 1990), this time frame is also suitable for deposition of the Tsäkkok Lens. Furthermore, lava flows have been documented within the Sofiebogen Group (Gołuchowska et al. 2012), which can possibly be linked to volcanic record preserved in the Tsäkkok Lens. Such link is in agreement with a possible shared Caledonian history with the Vestgötabreen Complex on Svalbard (Barnes et al. 2020a).

In summary, the current dataset suggests that Tsäkkok Lens sediments are unrelated to those of the Sarek and Vaimok lenses. The sediments could have been sourced from the Bamble-Kongsberg terrane in the south but appears to be more likely that it originated in association with Neoproterozoic basins preserved in the northern Caledonian Orogen. Further detrital zircon studies are required for such correlations to be unequivocally established. 


\section{CONCLUSIONS}

Field evidence for metasomatism of deformed metapelitic rocks is abundant in the Tsäkkok Lens. The timing of metasomatism is not recorded by zircon rims but likely occurred during the subduction-exhumation cycle of the lens in late Cambrian to Early Ordovician time. Instead, the rims indicate that the zircons were subjected to multiple tectonic events. The zircon cores provide a detrital record that is dominated by early Stenian, Calymmian, and Statherian populations with a subordinate Tonian population. The early Stenian population is rare within the Scandinavian Caledonides. A potential source terrain for this input is the Bamble-Kongsberg terrane in southern Norway, however, no detrital zircon records in the southern Scandinavian Caledonides are observed to be similar to the Tsäkkok Lens (i.e., lacking a dominant late Stenian signature). Neoproterozoic basins that are preserved in allochthonous positions in the northern extents of the Caledonides (e.g., metasedimentary rocks of the Gaissa Nappe and the Sofiebogen Group) have prominent early Stenian records with subordinate late Stenian input and are potentially good correlatives of the Tsäkkok Lens in Neoproterozoic time. Further investigations of the Tsäkkok Lens are required to establish such connections.

The following people are thanked for their efforts: P. Jeanneret, I. Klonowska, and L. Tual for their effort to conduct fieldwork in the Tsäkkok Lens; D. Schneider for helping with zircon mount preparation; S. Morfin and M. Kielmann-Schmitt for their assistance in conducting zircon U-Pb geochronology; G. Ziemniak for discussions of detrital zircon data. We are grateful for the comments and criticisms by F. Corfu as well as three anonymous reviewers. These reviews considerably improved the article. We are also very thankful for the efforts of editor T. Bajda. Funding for this research was provided by the National Science Centre of Poland (CALSUB project no. 2014/14/E/ST10/00321). The Swedish Research Council is thanked for financial support to the Vegacenter national laboratory (Dnr. 2017-00671). This is Vegacenter publication number 042 .

\section{REFERENCES}

Albrecht L.G., 2000. Early structural and metamorphic evolution of the Scandinavian Caledonides: a study of the eclogite-bearing Seve Nappe Complex at the Arctic Circle. Sweden. Lund University, Sweden [Ph.D. Thesis].

Andersson M., Lie J.E. \& Husebye E.S., 1996. Tectonic setting of post-orogenic granites within SW Fennoscandia based on deep seismic and gravity data. Terra Nova, 8, 558-566.

Andréasson P.-G., 2020. The continent-ocean (Seve-Köli) boundary in the Sarek-Padjelanta Mts. revisited: Swedish Caledonides. GFF, 142, 2, 125-138.https://doi.org/10.1080/ 11035897.2020.1748898.

Andréasson P.-G. \& Albrecht L., 1995. Derivation of $500 \mathrm{Ma}$ eclogites from the passive margin of Baltica and a note on the tectonometamorphic heterogeneity of eclogite-bearing crust. Geological Magazine, 132, 6, 729-738.

Barnes C., Majka J., Schneider D., Walczak K., Bukała M., Kośmińska K. et al., 2019. High-spatial resolution dating of monazite and zircon reveals the timing of subduction-exhumation of the Vaimok Lens in the Seve Nappe Complex (Scandinavian Caledonides). Contributions to Mineralogy and Petrology, 174, 5. https://doi.org/10.1007/ s00410-018-1539-1.

Barnes C.J., Walczak K., Janots E., Schneider D. \& Majka J., 2020a. Timing of paleozoic exhumation and deformation of the high-pressure Vestgötabreen complex at the Motalafjella Nunatak, Svalbard. Minerals, 10, 2, 125. https://doi.org/10.3390/min10020125.

Barnes C.J., Jeanneret P., Kullerud K., Majka J., Schneider D.A., Bukała M. et al., 2020b. Exhumation of the High-Pressure Tsäkkok Lens, Swedish Caledonides: Insights from the Structural and White Mica ${ }^{40} \mathrm{Ar} /{ }^{39} \mathrm{Ar}$ Geochronological Record. Tectonics, 39, 7, 1-23. https:// doi.org/10.1029/2020TC006242.

Be'eri-Shlevin Y., Gee D., Claesson S., Ladenberger A., Majka J., Kirkland C. et al., 2011. Provenance of Neoproterozoic sediments in the Särv nappes (Middle Allochthon) of the Scandinavian Caledonides: LA-ICP-MS and SIMS U-Pb dating of detrital zircons. Precambrian Research, 187, 181-200. https://doi.org/10.1016/j.precamres.2011.03.007.

Bergström U., Stephens M.B. \& Wahlgren C.-H., 2020. Polyphase (1.6-1.5 and 1.1-1.0 Ga) deformation and metamorphism of Proterozoic (1.7-1.1 Ga) continental crust, Idefjorden terrane, Sveconorwegian orogen. [in:] Stephens M.B. \& Weihed J.B. (eds.), Sweden: Lithotectonic framework, tectonic evolution and mineral resources, Geological Society of London Memoirs, 50, Geological Society of London, London, 397-434. https://doi. org/10.1144/M50-2018-34.

Bingen B. \& Soll A., 2009. Geochronology of magmatism in the Caledonian and Sveconorwegian belts of Baltica: synopsis for detrital zircon provenance studies. Norwegian Journal of Geology, 89, 267-290.

Bingen B., Andersson J., Söderlund U. \& Möller C., 2008. The Mesoproterozoic in the Nordic countries. Episodes, 31, 29-34.

Bukała M., Klonowska I., Barnes C., Majka J., Kośmińska K., Janák M. et al. 2018. UHP metamorphism recorded by phengite eclogite from the Caledonides of northern Sweden: P-T path and tectonic implications. Journal of Metamorphic Geology, 36, 5, 547-566. https://doi. org/10.1111/jmg.12306. 
Bukała M., Barnes C.J., Jeanneret P., Hidas K., Mazur S., Almqvist B.S.G. et al., 2020a. Brittle deformation during eclogitization of early Paleozoic blueschist. Frontiers in Earth Science, 8, 594453. https://doi.org/10.3389/ feart.2020.594453.

Bukała M., Majka J., Walczak K., Włodek A., Schmitt M. \& Zagórska A., 2020b. U-Pb Zircon Dating of Migmatitic Paragneisses and Garnet Amphibolite from the High Pressure Seve Nappe Complex in Kittalfjäll, Swedish Caledonides. Minerals, 10, 4, 295. https://doi. org $/ 10.3390 / \min 10040295$.

Coutts D.S., Matthews W.A. \& Hubbard S.M., 2019. Assessment of widely used methods to derive depositional ages from detrital zircon populations. Geoscience Frontiers, 10, 1421-1435. https://doi.org/10.1016/j.gsf.2018.11.002.

Ebbing J., Afework Y., Olesen O. \& Nordgulen Ø., 2005. Is there evidence for magmatic underplating beneath the Oslo Rift? Terra Nova, 17, 129-134. https://doi. org/10.1111/j.1365-3121.2004.00592.x.

Fassmer K., Froitzheim N., Janák M., Strohmeyer M., Bukała M., Lagos M., Münker C., 2021. Diachronous collision in the Seve Nappe Complex: Evidence from Lu-Hf geochronology of eclogites (Norrbotten, North Sweden). Journal of Metamorphic Geology, 00, 1-24. https://doi.org/ 10.1111/jmg.12591.

Gee D.G., Fossen H., Henriksen N. \& Higgins A.K., 2008. From the early Paleozoic platforms of Baltica and Laurentia to the Caledonide Orogen of Scandinavia and Greenland. Episodes, 31, 1, 44-51. https://doi. org/10.18814/epiiugs/2008/v31i1/007.

Gee D.G., Janák M., Majka J., Robinson P. \& van Roermund H., 2013. Subduction along and within the Baltoscandian margin during closing of the Iapetus Ocean and Baltica-Laurentia collision. Lithosphere, 5, 169-178. https://doi.org/10.1130/L220.1.

Gee D.G., Ladenberger A., Dahlqvist P., Majka J., Be'eri-Shlevin Y., Frei D. \& Thomsen T., 2014. The Baltoscandian margin detrital zircon signatures of the central Scandes. [in:] Corfu F., Gasser D. \& Chew D.M. (eds.), New Perspectives on the Caledonides of Scandinavia and Related Are, Geological Society Special Publications, 390, Geological Society of London, London, 131-155. https://doi.org/10.1144/SP390.20.

Gee D.G., Andréasson P.-G., Lorenz H., Frei D. \& Majka J., 2015. Detrital zircon signatures of the Baltoscandian margin along the Arctic Circle Caledonides in Sweden: The Sveconorwegian connection. Precambrian Research, 265, 40-56. https://doi.org/10.1016/j.precamres. 2015.05.012.

Gee D.G., Andréasson P.-G., Li Y. \& Krill A., 2017. Baltoscandian margin, Sveconorwegian crust lost by subduction during Caledonian collisional orogeny. GFF, 139, 36-51. https://doi.org/10.1080/11035897.2016.1200667

Gee D.G., Klonowska I., Andréasson P.-G. \& Stephens M.B., 2020. Middle thrust sheets in the Caledonide orogen, Sweden: The outer margin of Baltica, the continentocean transition zone and late Cambrian-Ordovician subduction-accretion. [in:] Stephens M.B. \& Weihed J.B. (eds.), Sweden: Lithotectonic framework, tectonic evolution and mineral resources, Geological Society of London Memoirs, 50, Geological Society of London, London, 517-548. https://doi.org/10.1144/M50-2018-73.
Gołuchowska K., Barker A.K., Majka J., Manecki M., Czerny J. \& Bazarnik J., 2012. Preservation of magmatic signals in metavolcanics from Wedel Jarlsberg Land, SW Svalbard. Mineralogia, 43, 179-197. https://doi.org/10.2478/v10002012-0007-1.

Hanmer S., Corrigan D., Pehrsson S. \& Nadeau L., 2000. SW Grenville Province, Canada: The case against post-1.4 Ga accretionary tectonics. Tectonophysics, 319,33-51.https:// doi.org/10.1016/S0040-1951(99)00317-0.

Jensen S., Högström A.E.S., Høyberget M., Meinhold G., McIlroy D., Ebbestad, J.O.R. et al., 2018. New occurrences of Palaeopascichnus from the Stáhpogieddi formation, Arctic Norway, and their bearing on the age of the varanger ice age. Canadian Journal of Earth Sciences, 55, 1253-1261. https://doi.org/10.1139/cjes-2018-0035.

Kirkland C.L., Bingen B., Whitehouse M.J., Beyer E. \& Griffin W.L., 2011. Neoproterozoic palaeogeography in the North Atlantic Region: Inferences from the Akkajaure and Seve Nappes of the Scandinavian Caledonides. Precambrian Research, 186(1-4), 127-146. https://doi. org/10.1016/j.precamres.2011.01.010.

Kjøll H.J., 2020. Late Neoproterozoic basin evolution of the magma rich Iapetus margin of Baltica. Norwegian Journal of Geology, 100. https://doi.org/10.17850/njg100-1-6.

Kullerud K., Stephens M.B. \& Zachrisson E., 1990. Pillow lavas as protoliths for eclogites: evidence from a late Precambrian-Cambrian continental margin, Seve Nappes, Scandinavian Caledonides. Contributions to Mineralogy and Petrology, 105, 1-10.

Ladenberger A., Be'eri-Shlevin Y., Claesson S., Gee D.G., Majka J. \& Romanova I.V., 2014. Åreskutan Nappe Caledonian Tectonometamorphic evolution of the A history revealed by SIMS U-Pb zircon geochronology. [in:] Corfu F., Gasser D. \& Chew D.M. (eds.), New Perspectives on the Caledonides of Scandinavia and Related Are, Geological Society Special Publications, 390, Geological Society of London, London, 337-368.

McLelland J.M., Bickford M.E., Hill B.M., Clechenko C.C., Valley J.W. \& Hamilton M.A., 2004. Direct dating of Adirondack massif anorthosite by U-Pb SHRIMP analysis of igneous zircon: Implications for AMCG complexes. Geological Society of America Bulletin, 116, 1299-1317. https://doi.org/10.1130/B25482.1.

Peck W.H., Selleck B.W., Wong M.S., Chiarenzelli J.R., Harpp K.S., Hollocher K. et al., 2013. Orogenic to postorogenic (1.20-1.15 Ga) magmatism in the Adirondack Lowlands and Frontenac terrane, southern Grenville Province, USA and Canada. Geosphere, 9, 16371663. https://doi.org/10.1130/GES00879.1.

Root D. \& Corfu F., 2012. U-Pb geochronology of two discrete Ordovician high-pressure metamorphic events in the Seve Nappe Complex, Scandinavian Caledonides. Contributions to Mineralogy and Petrology, 163, 769-788. https://doi.org/10.1007/s00410-011-0698-0.

Slagstad T. \& Kirkland C.L., 2017. The use of detrital zircon data in terrane analysis: A nonunique answer to provenance and tectonostratigraphic position in the Scandinavian Caledonides. Lithosphere, 9, 1002-1011. https:// doi.org/10.1130/2018.2541(05).

Sláma J., Košler J., CondonD.J., Crowler J.L., Gerdes A., Hanchar J.M. et al., 2008. Plešovice zircon - A new natural reference material for $\mathrm{U}-\mathrm{Pb}$ and $\mathrm{Hf}$ isotopic 
microanalysis. Chemical Geology, 249, 1-2, 1-35. https:// doi.org/10.1016/j.chemgeo.2007.11.005.

Stephens M.B. \&Weihed J.B., 2020. Polyphase (1.9-1.8, 1.5-1.4 and 1.0-0.9 Ga) deformation and metamorphism of Proterozoic (1.9-1.2 Ga) continental crust, Eastern Segment, Sveconorwegian orogen. [in:] Stephens M.B. \& Weihed J.B. (eds.), Sweden: Lithotectonic framework, tectonic evolution and mineral resources, Geological Society of London Memoirs, 50, Geological Society of London, London, 351-396. https://doi.org/10.1144/M50-2018-57.

Stephens M.B., 2020. Upper and uppermost thrust sheets in the Caledonide orogen, Sweden: Outboard oceanic and exotic continental terranes. [in:] Stephens M.B. \& Weihed J.B. (eds.), Sweden: Lithotectonic framework, tectonic evolution and mineral, Geological Society of London Memoirs, 50, Geological Society of London, London, 549-575. https://doi.org/10.1144/M50-2018-73.

Thelander T., 2009: Bedrock map The Caledonides in northern Sweden, northern part, scale 1:250 000. Sveriges Geologiska Undersökning, K222:1.

Vermeesch P., 2004. How many grains are needed for a provenance study? Earth and Planetary Science Letters, 15, 441-451. https://doi.org/10.1016/j.epsl.2004.05.037.

Wala V.T., Ziemniak G., Majka J., Faehnrich K., McClelland W.C., Meyer E.E. et al., 2021. Neoproterozoic stratigraphy of the Southwestern Basement Province, Svalbard (Norway): Constraints on the Proterozoic-Paleozoic evolution of the North Atlantic-Arctic Caledonides. Precambrian Research, 358. https://doi.org/10.1016/ j.precamres.2021.106138.
Wiedenbeck M., Alle P., Corfu F., Griffin W.L., Meier M., Oberli F. et al., 1995. Three Natural Zircon Standards for U-Th-Pb, Lu-Hf, Trace Element and REE Analyses. Geostandards Newsletter, 19, 1-23.

Zachrisson E. \& Stephens M.B., 1984. Mega-structures within the Seve Nappes, southern Norrbotten Caledonides, Sweden. [in:] Armands G. \& Schager S. (eds.), Abstracts 16e Nordiska Geologiska Vintermötet, Stockholm 9-13 januari 1984, Meddelanden från Stockholms universitets geologiska institution, 255, Department of Geology, Stockholms Universitet, Stockholm, 241.

Ziemniak G., Kośmińska K., Schneider D.A., Majka J., Lorenz H., McClelland et al., 2019. Defining tectonic boundaries using detrital zircon signatures of Precambrian metasediments from Svalbard's Southwestern Caledonian Basement Province. [in:] Piepjohn K., Strauss J. V., Reinhardt L. \& McClelland W.C. (eds.), Circum-Arctic Structural Events: Tectonic Evolution of the Arctic Margins and Trans-Arctic Links with Adjacent Orogens, Special Paper, 541, Geological Society of America, 1-14.

Supplementary data associated with this article (Tabs. S1 and S2) can be found, in the online version, at: https://doi.org/10.7494/geol.2021.47.1.21.

Table S1. Zircon U-Pb geochronological data of sample TS17$35 \mathrm{~A}$ and reference materials obtained from the University of Ottawa

Table S2. Zircon U-Pb geochronological data of sample TS17-35A and reference materials obtained from the Vegacenter 